\title{
THE RIGHT OF ACCESS TO THE SEA OF AFRICAN LAND-LOCKED COUNTRIES*
}

\author{
By ZdeneK Červenka
}

Out of the 28 land-locked countries of the world fourteen are in Africa: Botswana, Burundi, Central African Republic, Chad, Lesotho, Malawi, Mali, Niger, Rwanda, Swaziland, Uganda, Upper Volta, Zambia and Zimbabwe (Rhodesia) ${ }^{1}$.

The term land-locked literally means having no sea-coast whatsoever, being completely cut off from the sea, access to which depends on the consent of the neighbouring states for using their routes to the sea and their seaport facilities. The situation can be further complicated when the transit state is also a landlocked state such as Malawi (providing transit for Rwanda and Burundi) or Rhodesia (providing or rather having provided transit for Zambia). In a broader sense of the word the land-locked position called "land-lockedness" is not merely a question of access to the sea but a matter of access to the wide network of communications with the outside world of which the sea forms only a part, though the most important one. The absence of free access to the means of communications with the outside world significantly affects the processes of political, economic and social development. South Africa's control of Lesotho's and Swaziland's air traffic, telex and telephone communications and even of postal services (most mail is moved to both countries through South Africa) illustrates the point.

The reason why the access to the sea is of paramount importance to African land-locked countries is simply because trade in Africa is still structured externally not internally. In 1970 Africa imported about $\$ 10.970$ mill. worth of goods out of which $\$ 730$ mill. or only 6.7 per cent came from other African countries. With Africa's exports to the world representing about $\$ 12.000$ mill. the percentage figure for intra-African exports works out at 6 per cent.

The small volume of intra-African trade is particularly striking when compared with the fact that Africa imports more from any single major economic power - Great Britain, France, USA, Japan and Germany - then it does from other African countries taken together. It also does twice the amount of trade with other parts of the developing world than with itself. Finally, intra-African trade is smallest of all other intra-continental trades of developing countries - Asia trades 21.3 per cent internally, Latin America 11.8 per cent.

As the bulk of international trade is predominantly still carried by sea access to the sea is synonymous with access to the world market. Besides, transporting persons across the oceans is free in a sense in which over-land transport can never be because political frontiers have to be crossed, or air transport cannot be because overflying rights have to be assured. The land-locked African countries are not only without direct access to the sea, but in the majority of cases are also remote from the sea, sometimes separated from transit ports by very great distances. For example the "shortest" land connection of the Chad with the

\footnotetext{
* The article is based on the proceedings of the seminar on "The Land-locked Countries of Africa“ held in Oslo 24-28 September 1972 and directed by the author who also edited the book containing the papers submitted tc the seminar to be published in autumn 1973.

1 The other land-locked countries are: Afghanistan, Austria, Bolivia, Czechoslovakia, Holy See, Hungary, Laos, Liechtenstein, Luxembourg, Mongolia, Nepal, Paraguay, San Marino, Switzerland.
} 
sea from Fort Long to Lagos is $2.050 \mathrm{~km}$, the other three alternatives (Fort Long-Pointe Noire, Fort Archambault-Pointe Noire and Abeche-Port Sudan) being substantially longer ranging from 2.400 to $3.000 \mathrm{~km}$.

It should be pointed out that many of the economic problems of land-locked countries in Africa are shared with their neighbours and are an integral part of the general problems of economic development. However, the land-locked situation adds a new dimension of difficulty to the economic development of the countries concerned. The position of producers (and of exporters and importers) in a land-locked country may be compared with that of many of their counterparts in inland areas of a large coastal country such as the Federal Republic of Nigeria: eight out of its 12 states are land-locked. There is of course one fundamental difference. Unlike the land-locked country depending on the transit routes and port facilities of other states the distant area of a large coastal state is an integral part of a single political unit with identical currency, regulations, and tariffs. It possesses the capability of compensating the distant inland region for any additional costs arising from its distance from the sea and to correct any disparities in income arising from that cause between the "land-locked" region and the coastal area by means of preferential tariffs, taxes, credits, etc.

There are three different views of the legal nature of the right of access to the sea $^{2}$.

The first is to view the right of access to the sea as already embodied in international law, for land-locked states already enjoy the right to use the high seas, on the same footing as maritime states by virtue of the principle of freedom of the high seas. The high seas are open to all nations, hence also to land-locked states. This right of access to the sea is therefore regarded as a specific and inherent right without which the exercise of the fundamental right concerning the use of the high seas would be impossible of realization.

The second view places the right of access to the sea in the category of contractual rights accorded on the basis of a quid pro quo and therefore revocable.

The third view is to look upon the right of access to the sea as a legal relationship between the land-locked country and its coastal neighbour, developed within the framework of relevant legal principles and political and economic realities.

The first view is the one held by most land-locked countries, the second by the majority of coastal states while the third provides a basis for the compromise between the first two.

The present state of the law on the subject reflects adjustment of interest and purpose. For example, a paper submitted by seven states ${ }^{3}$ to the Committee on the Peaceful Uses of the Sea-Bed and the Ocean Floor beyond the Limits of National Jurisdiction contained a proposal to be included in an International Sea-bed Convention which would codify certain rights for land-locked States ${ }^{4}$. According to the proposal, the International Authority would "in accordance

\footnotetext{
2 For the development of principle of the right of free access to the sea see M. I. Glassner, Access to the Sea for Developing Land-locked States, The Hague: Martinus Nijhoff, 1970; G. Lang, Boliviens Streben nach freiem Zugang zum Meer, Hamburg: Gesellschaft für Völkerrecht und auswärtige Politik, 1966; J. H. Merryman and H. D. Ackerman, International I.aw, Development and the Transit Trade of Land-locked States - The Case of Bolivia, Hamburg: Forschungsstelle für Völkerrecht und ausländisches öffentliches Recht der Universität Hamburg, 1969.

Of a particular legal interest are the proceedings of the Fifth Committee (Question of Free Access to the Sea of Land-locked Countries) of the United Nations Conference on the Law of the Sea held in Geneva from 24th February to 27 th April 1958.

3 Afghanistan, Austria, Belgium, Hungary, Nepal, Netherlands and Singapore.

4 Doc. A/AC. $138 / 55$ of August 19, 1971.
} 
with the right of free access of land-locked countries to the sea - recommend arrangements between the land-locked State and one or more other member States designed to ensure effective freedom of communication between the landlocked State and the area under license, for the purpose of exploration, exploitation, including storage and processing and marketing of the mineral resources of that area". The example shows how the rights of land-locked states have become recognized by the international community, are guaranteed under general international law, and how their infringement may become a matter of public concern calling for involvement by an appropriate international body. The claims of land-locked states cannot therefore be regarded as subordinate to those of the coastal states but should be treated as of equal value. It would indeed frustrate the purpose of the right of access if its implementation were to be left completely at the sovereign discretion of coastal states which may not acknowledge a duty to facilitate the exercise of this right ${ }^{5}$.

Although the fact that access to the sea for land-locked states in general and the developing ones in particular is an essential pre-requisite for strengthening the bonds between all members of the international community in terms of trade and economic co-operation and development is well established, there is, however, still very little agreement on the conditions under which the land-locked states should exercise their right. Article 3 of the Convention on the High Seas adopted on April 29, 1958 is far from a satisfactory solution because it refers to "common agreement" and "reciprocity" leaving the granting of the right of the landlocked states more or less at the discretion of the coastal states ${ }^{6}$. Similarly, the Convention on Transit Trade of Land-locked States concluded on 8th July, 1965, in New York, though making an important step forward in the progressive development of this branch of international law, does not yet satisfy the expectations of the land-locked countries as it still does not guarantee them the freedom of access they desire. This Convention cites U. N. General Assembly Resolution 1028 (XI) and Article 3 of the 1958 Geneva Convention on the High Seas, then reaffirms eight principles adopted by the UNCTAD supporting "the right of each land-locked State of free access to the Sea" Once again, however, the actual obligations of the coastal states are apparently envisaged as moral rather than legal as the principles contain circumlocutions and qualifications: “... said countries should be afforded..., on the basis of reciprocity, free and unrestricted transit, in such a manner that they have free access to regional and international

5 V. Pechota "The Right of Access to the Sea" in: The Land-locked Countries of Africa, edited by Z. Cervenka, Uppsala: The Scandinavian Institute of African Studies, 1973.

6 Article 3 of the Convention on the High Seas adopted by the United Nations Conference on the $\mathrm{Law}$ of the Sea on April 29, 1958 at Geneva stipulated the rights of the land-locked countries in the following way:

1. In order to enjoy the freedom of the seas on equal terms with coastal States, States having no sea-coast should have free access to the sea. To this end States situated between the sea and a State having no sea-coast shall by common agreement with the latter and in conformity with existing international convention accord:

a) To the State having no sea-coast, on a basis of reciprocity, free transit through their territory; and

b) To ships flying the flag of that State treatment equal to that accorded to their own ships, or the ships of any other States, as regards access to seaports and the use of such ports.

2. States situated between the sea and a State having no sea-coast shall settle, by mutual agreement with the latter, and taking into account the rights of the coastal State or of transit and the special conditions of the State having no sea-coast, all matters relating to freedom of transit and equal treatment in ports, in case such States are not already parties to existing international conventions. For the text of the Convention see 450 United Nations Treaty Series (UNTS) 82.

At the time of the Geneva Conference none of the African land-locked states attained independence. The only land-locked countries present were: Afghanistan, Austria, Bolivia, Byelorussian Soviet Socialist Republic, Czechoslovakia, Holy See, Hungary, Laos, Luxembourg, Nepal, Paraguay, San Marino and Switzerland. 
trade..."; "The State of transit, while maintaining full sovereignty over its territory, shall have the right to take all indispensable measures to ensure that the exercise of the right of free and unrestricted transit shall in no way infringe its legitimate interests of any kind"; "... the conclusion of regional and other international agreements in this regard should be encouraged by all States".

The Convention was designed primarily to guarantee to land-locked states those links with the outside world which are indispensable for their economic development or even their survival as with the land-locked countries of the southern Sahara. At the same time, the Convention provides extensive safeguards for transit states. The deficiencies of the Convention which stresses the moral rather than the legal obligations of the transit states, have been pointed out above. Furthermore, the Convention deals only with access to the sea of the transit traffic and fails to specify arrangements which would deal with the totality of the problems of land-locked countries. For example, the original proposal of the majority of land-locked countries was that a "free zone should be provided at the ports of entry or exit in the country of transit for transit goods which should be under the control of the customs authorities of the land-locked countries". This proposal was considerably weakened by substituting the wording, "free zones and other custom facilities may be provided . . ." Finally, the Convention on Transit Trade of Land-locked States was conceived as a universal treaty, designed to meet the needs of all land-locked states, including developed countries such as Austria, Switzerland, and Czechoslovakia. The political setting of European land-locked states is fundamentally different from that of the land-locked countries of Africa in general and of southern Africa in particular. Although the Economic Commission for Africa said about the Convention that "its ratification and its entry into force will safeguard the rights of land-locked countries and facilitate the conclusion of bilateral agreements" 7 , none of the African States followed the example of Nigeria and ratified the Convention.

There are two types of arrangements by means of which the African land-locked countries seek to offset the handicap of their geographic position:

1. bilateral agreements with the transit and coastal countries;

2. regional economic institutions established by multinational treaties.

The aims of regional economic arrangements are to promote trade, stimulate production, provide enhanced investment opportunities and, in some cases, to facilitate the movement of labour, capital and goods. Needless to say, such arrangements have political implications.

The experience of economic integration in Africa shows that gains are not necessarily assured. While common culture, history, language, geographical proximity, and compatibility of economic and political systems in the countries participating in a regional arrangement contribute to its success, while international support in the form of technical assistance and investment has an important role, it is the co-operation among participating countries that is decisive. For regional co-operation to succeed, it requires participating states to view projects in terms of regional rather than national benefits.

The specific problems that arise when regional co-operation is being planned or implemented are numerous. Some relate to the small volume of intra-regional

7 ECA, Transit Problems of African Land-locked States, E/CN 14/TRANS/29, 24 August 1966, p. 75. 
trade and economic relations in general. But the most difficult problem of all is to arrange a satisfactory distribution of benefits. Unless all parties feel that it is of some benefit to them, the aims of regional co-operation cannot be achieved ${ }^{8}$.

In Africa, all land-locked countries except Malawi and Burundi belong to some existing grouping for economic co-operation. These groupings vary in their aims and in the degree to which they accommodate the specific needs of the developing countries.

1. UDEAC: The land-locked developing countries of equatorial Africa, Chad and the Central African Republic, have participated in the Union Douanière et Economique de l'Afrique Centrale (UDEAC). This customs and economic union, which came into being on 1 January 1966, resulted from the association of Cameroon with the Equatorial Customs Union (UDE), established in 1956 to include Congo and Gabon, as well as Chad and the Central African Republic. Apart from the common external tariff, notable features of UDEAC include a common investment code, a common central bank, a solidarity fund, consultation on the location of industry, some common services, and the "taxe unique". However, in April 1968, Chad and the Central African Republic withdrew from UDEAC to create, in conjunction with the Democratic Republic of the Congo, the Union des Etats de l'Afrique Centrale (UEAC). This action resulted in part from the belief of these two countries that measures to allow them to benefit satisfactorily from UDEAC were not being implemented. Following some special arrangements to benefit the Central African Republic, that country returned to UDEAC in December 1968. The Solidarity Fund of UDEAC (which derives from earlier provisions of UDE) is of particular interest to the land-locked countries in the Union. Article 38 of the UDEAC Treaty states:

In order to take account of possible errors in the designation of the consuming State and of the benefits derived from transit operations by coastal States in particular, a percentage of the import duties and charges collected by the joint Customs Offices of the five States shall, in a spirit of solidarity, be paid into a Joint Solidarity Fund ${ }^{9}$.

As in the case of the UDE Fund, Chad and the Central African Republic have benefited substantially from the UDEAC Fund.

2. The West African Economic Community: The West African Economic Community, comprising Dahomey, Ivory Coast, Mauritania, Senegal and three landlocked countries - Niger, Mali and Upper Volta - was established in 1970, replacing the West African Customs Union. Its objectives are the improvement of the infra-structure for distribution, the development of transport and communications, the harmonization of industrial development and the expansion of intra-African trade.

In April 1968, the West African Regional group was established which includes, in addition to the seven members of UDEAC: Nigeria, Ghana, Liberia, Guinea and Mauritania.

\footnotetext{
8 An outline of the problems involved in regional economic arrangements was prepared in January 1970 by a group of experts appointed by the Secretary-General of UNCTAD to study the problems of developing land-locked countries. The paper is entitled Regional Economic Arrangements (Background

9 "Treaty establishing a Central African Customs and Economic Union", UNCTAD document Td/L. 5.
} 
3. OCAM: The Afro-Malagasy and Mauritius Common Organisation (OCAM), established in 1966, embraces fifteen French-speaking countries in Africa. Among them are the land-locked countries of the Central African Republic, Upper Volta, Rwanda, Chad and Niger. The objectives of the organization, which are "the strengthening of solidarity between its members, raising the standard of living of its peoples and harmonizing their economic policies and development plans", deal with the problems of land-locked members only in general terms.

4. Conseil de l'Entente: In 1959, Niger and Upper Volta, with Dahomey and the Ivory Coast, formed the Conseil de l'Entente, and in 1966 adopted a new Convention including Togo among the members. Economic arrangements include the Mutual Aid and Loan Guarantee Fund which provides security for foreign investment in the area and promotes co-operative economic activities. The member states of the Entente decided in January 1968 to pursue studies on the extension of the Abidjan-Niger railway and on the improvement of road communications between them. The land-locked member states are free to use the Mutual Aid and Loan Guarantee Fund for their own or multinational purposes, thus being able to strengthen economic co-operation with the coastal member states.

5. The East African Community: The East African Community, established in 1967, at present comprises Uganda, Kenya and Tanzania, but is of wider interest since its expansion is envisaged and applications for membership have been received from Zambia, Ethiopia, Somalia, Rwanda, Burundi and Swaziland. Features of the present arrangements include common services (transport, customs, education, communications) and measures to try to secure a satisfactory distribution of benefits by means of transfer taxes and the investment policy of the East African Development Bank. Transfer taxes are a temporary measure designed to encourage industrial development in Tanzania and Uganda.

The treaty for East African co-operation which created the East African Community provided for the establishment of four corporations related to transport and communications for the member states which are of a particular interest to land-locked Uganda. They are:

1. The East African Railways Corporation, concerned with the operation of rail, road, and inland waterways transport and inland waterways ports;

2. The East African Harbours Corporation, concerned with the operation of harbour services and facilities;

3. The East African Airways Corporation, concerned with the operation of air transport services and facilities within the member states and with other countries;

4. The East African Ports and Telecommunications Corporation.

Although progress has been encouraging since the regional arrangements began to change from originally narrow objectives to wider spheres of co-operation, embracing co-ordination of planning, trade and industrial development, a number of problems are still being encountered. Among them is the lack of machinery for implementing joint decisions affecting a group of countries. Furthermore, the political instability caused by a series of coup d'états has retarded the progress towards more realistic joint undertakings. Moreover, the withdrawal of some member states from existing organizations has created an atmosphere of uncer- 
tainty. Commenting on the performance of OCAM, Louis Sabourin pointed out that "ten years after its creation OCAM is far from being a success. It has not been able to foster the economic development of its members in general, the less of the land-locked countries"10.

Another impediment to the progress of African regional economic co-operation is that too much attention has been devoted to the preservation of old links developed in the period of colonial rule. Pierre Alexandre has shown in his analysis of the developments in Afrique Occidentale Française (AOF) after independence that with regard to Mali, Upper Volta, and Niger the extent to which the former colonial political boundaries remain significant: "in purely geographical terms one could well have expected a shift of communication links to the benefit of former British colonies. Yet the only attempt in this direction (Upper Volta - Ghana) was a total failure"11.

Both the United Nations Economic Commission for Africa (ECA) and the Organization of African Unity (OAU) sponsor various kinds of regional co-operation in Africa. OAU, although essentially a political organization, devotes considerable attention to the promotion of inter-African trade. It sponsored the First All African Trade Fair in Nairobi in 1972. Of course, OAU is not a regional but a continental organization ${ }^{12}$, with an important role to play in co-ordinating Africa's regional organizations and steering them towards the goal of continental economic integration.

Thus, the regional groupings of African states, once regarded as incompatible with the Charter of OAU, have become, with the sole exception of OCAM, a means of strengthening the Organisation of African Unity. This is not only desirable, but also essential in the field of economic co-operation, and was made clear by the resolution on Regional Economic Groupings adopted at the Kinshasa Conference in September 1967, which notes that "economic co-operation in Africa is suffering from lack of co-ordination in all fields of activity". It also welcomed the efforts of member states to form regional groupings. It recommended:

1. "that all Member States encourage the formation of economic groupings by all appropriate means, with the final objective of integrating the Continent;

2. that Member States be asked to promote the exchange of information in this field through the Secretary-General of OAU"13.

A year later, at Algiers, the Council of Ministers of OAU, in its resolution on "Regional Groupings and Market Integration"14, considered that "market integration at the regional level (regional groupings) would not only bring about the basis for necessary industrialization of the continent but would also enhance interAfrican trade" and that "the widening of regional groups is one of the prerequisites for the economic integration of the Continent". The Council re-

\footnotetext{
10 Louis Sabourin: "Seven land-locked countries of French speaking Africa. Problems and Prospects" in: The land-locked countries of Africa, Uppsala; The Scandinavian Institute of African Studies, 1973.

11 Pierre Alexandre: "Afrique Occidental Française (AOF) and after". Ibid.

12 The difference between a continental and a regional organisation is not only in scope but also in purpose and aims. The scope of OAU is apparent from the preamble as well as from the purposes and principles referring to Africa as a continent and excluding also classification under Article 52 of the UN Charter which specifically refers to "regional arrangements or agencies for dealing with such matters relating to the maintenance of international peace and security". The members of OAU feel matters relating to the maintenance of international peace and security". The members of OAU feel
that their disputes should be settled within the African framework; therefore, OAU has never found it necessary to refer inter-African disputes to the Security Council in accordance with Article 52 of the UN Charter, even though a number of them involved armed hostility (e. g. the Algeria-Morocco dispute in 1963). In this respect, OAU is different from the Organisation of American States (OAS), the Charter of which expressly defines OAS as a "regional agency". Article 1 of the OAS Charter states ". . Within the United Nations, the Organisation of American States is a regional agency." $13 \mathrm{CM} /$ Res. 125 (IX).

14 CM/Res. 159 (IX).
} 
commended inter alia "the broadening of the existing regional groupings and the extension of the economic sectors and the commodities (or groups of commodities) that could be covered within a regional grouping".

In fact, all resolutions adopted both by the Council of Ministers and the Assembly of Heads of State and Government on various aspects of regional groupings (e. g. Resolution on Inter-African Co-operation ${ }^{15}$, Resolution on Industrialization ${ }^{16}$, and the resolution on the formation of an Expert Committee to Study the Draft Inter-African Convention Establishing an African Technical Assistance Programme adopted at the 1972 OAU Summit at Rabat) ${ }^{17}$ testify to the determination of the African countries to break down the barriers inherited from the colonial era.

As far as the problems of African land-locked countries are concerned, until recently they have been regarded by OAU as problems of economic underdevelopment, and as such were considered to be a matter for the United Nations. The UNCTAD conference recognized that:

"the position of the land-locked developing countries, in particular, because of the high costs of transportation, the poor development of their infrastructure, inadequate and inconvenient transport, storage and port facilities in most transit countries, the lack of opportunity or arrangements to use their own transport facilities and, in general the unfavourable trend of transport tariff and charges, is a factor seriously inhibiting the expansion of their trade and economic development" 18.

So far, however, no measures have been taken directly by OAU, which holds the view that the specific problems of land-locked countries are a part of the more general problems of economic development.

For example, the Economic Commission for Africa, in its study "Transit problems of African land-locked States of 1966"19 saw the problem in economic and legal terms only20. The "non-political" attitude adopted by ECA is illustrated in this study, which was being compiled at the time when the Rhodesian crisis dominated African politics and which was concluded only ten weeks before the Rhodesian white minority regime unilaterally declared independence. The political implications of the transit problems of those land-locked countries depending on Rhodesian transit were not even mentioned ${ }^{21}$.

Exceptionally, ECA mentioned the rupture of relations between Mali and Senegal in 1960. Although this entailed major changes in terms of transit for Mali, which had to readjust its external trade through a new transit route via the Ivory Coast, it was only a marginal problem compared to that which land-locked states faced following Rhodesia's UDI. Besides, economic relations between Mali and Senegal were resumed in 1963, leaving Mali with a choice of two transit routes.

The expectation of the Economic Commission of Africa that "the establishment of the Organization of African Unity brings into this matter not only the

\footnotetext{
15 CM/Res. 123 (IX).

16 CM/Res. 124 (IX).

17 CM/Res. 276 (XIX)

18 Special measures related to the particular needs of the land-locked developing countries. A Resolution adopted by the United Nations Conference on Trade and Development, 19th May 1972 in Santiago,

19 E/CN 14/TRANS/29 of 24th August 1966.

20 "The problem of free access of a land-locked country to the open sea is part of the more important problem of freedom of transit. The latter includes the fundamental economic interests of and legal safeguards for the countries concerned". Ibid. p. 3.

21 The study enumerates issues involved in transit problems of land-locked states as "legal, technical, economic, as well as social, the latter influencing the actual importance of the first three".
} 
new spirit of brotherhood, but also the real conditions for implementing the new terms of transit, advantageous both to land-locked and transit countries" 22 still remains to be fulfilled.

Although awareness of the peculiar situation of the developing land-locked countries has steadily increased, leading to greater understanding of their problems, the actual record of achievement is rather depressing. The appeals of the last two United Nations Conferences on Trade and Development in 1968 and in 1972, which called on the developed countries and international organizations to provide technical and financial assistance to the land-locked developing countries in order to strengthen their economic structure, transport, and communication infrastructure and to provide for the establishment of transit areas and port facilities, went virtually unheeded. Equally disappointing was the attitude of the developing countries themselves. The New York Convention on Transit Trade of Landlocked States of July 1965 was a culmination of the efforts of the land-locked states at the first UNCTAD conference in 1964. But Nigeria was the only African transit state south of the Sahara to ratify it.

It has become apparent that the specific needs of African land-locked countries should be met by an African convention concluded under the auspices of the Organization of African Unity. This was suggested by the Economic Commission for Africa in 1966. The ECA study of the transit problem of the African landlocked countries emphasised the advantage that "Africa is endowed with potentialities to enable it to deal with the problems of co-ordination". The same study saw OAU as "the last resort for solving any misunderstanding" which might arise out of the arrangements between the coastal and land-locked countries ${ }^{23}$.

In respect of transit routes, African land-locked countries fall into the following four categories:

(i) Those which have direct railway links with an ocean port

Botswana: Durban, East London, Port Elizabeth, and Cape Town in South Africa.

Lesotho: Durban in South Africa.

Malawi: Beira and Nacala in Mozambique.

Mali: Dakar in Senegal.

Rhodesia: Beira and Lourenco Marques in Mozambique.

Swaziland: Lourenco Marques in Mozambique; Durban in South Africa.

Uganda: Mombasa in Kenya.

Upper Volta: Abidjan in Ivory Coast.

Zambia: Beira in Mozambique; Lobito in Angola; Dar-es-Salaam in Tanzania (1976).

(ii) Those which use road transport to reach a rail-head

Chad: By road to Maiduguri in Nigeria, then by rail to Lagos.

Niger: By road to Parakou in Dahomey, then by rail to Cotonou.

Rwanda: By road to Kigali in Uganda, then by rail to Mombasa in Kenya.

(iii) Those which use river or lake transport to reach a rail-head

Burundi: By lake to Ujiji in Tanzania, then by rail to Dar-es-Salaam.

Central African Republic: By river to Brazzaville in Congo, then by rail to Pointe Noire.

22 Ibid., p. 7.

$23 \mathrm{E} / \mathrm{CN} / 14 / \mathrm{TR}$ ANS/29 of 24th August 1966. 


\section{(iv) Those which have direct road links with an ocean port}

Zambia: Dar-es-Salaam in Tanzania.

In the absence of any general agreement on the rules and principles governing transit and access to the sea by the land-locked countries of Africa which take into account specific economic and political conditions, most of the facilities which these fourteen countries have available are based on bilateral ad hoc agreements with the coastal countries. An all-African convention dealing with the problem of access should not only make provision for further measures to alleviate the problems of Africa's least developed countries but also should promote continental co-operation. OAU should therefore sponsor a conference for its landlocked members and their transit and coastal neighbours in order to agree on principles which would provide a basis for bilateral arrangements between the land-locked and coastal states. The following principles should be embodied in the agreement on the issues of transit, trade routes, and access to the sea:

1. Every land-locked state has the right to free access to the sea.

This right derives from the fundamental principle of the freedom of the high seas. Freedom of the high seas has no meaning for land-locked countries unless the right of access to the sea is first guaranteed. Similarly, the principle of the equal sovereign rights and political and economic independence of all members of the international community irrespective of their geographical position would be seriously impaired should free access be denied to the land-locked countries. As pointed out in Principle I of the Convention on Transit Trade of Land-locked States, "the recognition of the right of each land-locked state of free access to the sea is an essential principle for the expansion of international trade and economic development"24.

2. Every African land-locked state has the right on terms of complete equality with maritime states to fly its flag on vessels which are duly registered in a specific place on its territory, that place being the port of registry for such vessels.

The right of land-locked states to fly a flag at sea has already become a principle of international law recognized and applied by all states. The Declaration recognizing the right of states without a sea coast to fly a flag at sea was unanimously adopted fifty years ago at the Barcelona Conference on the Freedom of Navigation and Transit in 1921 and confirmed by a number of international conventions.

3. The maritime state shall accord the vessels of land-locked states treatment equal to that en joyed by its own vessels in its ports.

The granting of free access to ports and other facilities with respect to navigation and commercial operation of vessels, their cargoes, and passengers represents compensation to a land-locked state for the disadvantages arising from its geographical position.

4. Countries situated between the land-locked state and the sea coast shall allow the transit of persons and goods proceeding from the land-locked state to the sea and vice versa by road, rail, waterway and air. Similarly, all states shall, on the basis of reciprocity, afford the land-locked state free and unrestricted transit in such a manner that they have free access to regional and international trade.

24 Doc. A/5906, Annex II, p. 6. 
The right of free access to the sea of land-locked states comprises the right of free transit through the territory of coastal states for persons and goods, irrespective of the mode of transport used. It also comprises exemption from the coastal states' custom regulations and duties, and from any payment other than payment for services rendered. The transit states are entitled to take measures to ensure that the exercise of the right of free access by the land-locked states shall in no way infringe their security and public health. Passage across the territory of another state requires a bilateral agreement, but a transit state should not be able to refuse to negotiate, or employ arbitrarily its right concerning security and health measures in order to thwart such a negotiation, without thereby incurring international responsibility.

5. For the purpose of unrestricted and duty-free movement of goods between a land-locked state and the sea-coast, a special zone in the ports of the coastal state shall be established in agreement with the coastal state and placed under the control of the custom authorities of the land-locked state.

The free zone, however, should remain subject to the jurisdiction of the coastal state, especially with regard to safety of operation, working conditions and public health. In cases where the volume of transit traffic does not justify the expense of establishing a separate free zone, the coastal state should permit the bonded storage of transit goods under favourable conditions in respect of port charges and customs declarations. The 1963 agreement between Senegal and Mali and the 1965 agreement between Niger and Dahomey in respect of port facilities may serve as a good example for other African states.

6. An international authority within the framework of OAU shall be established to provide for inter-governmental consultation to ensure that the needs and problems of both land-locked and transit states are kept under review. The same authority shall also provide the machinery for the settlement of disputes which may arise between the member states of the proposed Convention.

The international authority, on which both the land-locked and transit states should be represented, could facilitate the concluding of agreements between land-locked states and their transit neighbours. The authority should also seek to simplify procedures and documentation and to provide for instruction of the officials of both land-locked and transit states working in ports and on transit routes. The authority should also facilitate the free circulation of road vehicles of the parties to the convention across frontiers on a reciprocal bais, the free movement of rolling stock of states which have interconnecting railways, the freedom of navigation on inland waterways for vessels of land-locked countries, and the co-ordination and integration of transport networks.

These principles alone will not, of course, solve the practical problems of transit and trade of the African land-locked countries. Under the present circumstances, it is the low operational efficiency of the ports and the poor state of the communications network on which the land-locked countries depend which puts them at a great disadvantage. The obsolete equipment, the poor condition of both railway tracks and roads built originally by the colonial powers, and the inefficient management of the transport system call for radical improvements. The solution lies in a complex approach to the problem. Most of the African land-locked and transit states are too small and too underdeveloped to be able to achieve significant improvements of their communication networks indepen- 
dently. Fundamental change in this field requires combined efforts by all the states concerned. Multi-national projects for the improvement of the regional infrastructure could bring about the necessary change. While African countries can set the example of a united approach to the problems of the land-locked countries by displaying their solidarity with these states, they cannot, without external aid, finance the improvement of roads, railways, inland waterways, airports, and postal and telecommunication systems. These measures require heavy investment. International aid will therefore play a vital role. It is important that the critical nature of investment in transport for the African land-locked countries be recognized by the developed countries and international bodies providing financial and technical assistance. The aid-financed projects within either transit or land-locked countries should be based on an integrated approach. This means that transport projects in the land-locked countries should be considered in relation to the merits of possible alternative routes within the transit countries.

If the economic and political stability of African land-locked states is to be achieved, the attitudes and actions of all African countries will be of decisive importance, for they must improve the position of the land-locked states before international assistance to that purpose can be successfully solicited.

Finally, a point should be made about whether the proposed Convention can safeguard the interests of the land-locked countries in Rhodesia, the Portuguese colonies of Mozambique and Angola, and South Africa, all of which are important transit and coastal states in southern Africa. While these countries will not be eligible to participate in an OAU Convention accommodating the needs of African land-locked countries, the Convention shall provide a basis on which the land-locked countries concerned could enter into bilateral agreements. The legal and political impact of a Convention representing a consensus of independent African states could hardly be ignored by the world community. It would considerably strengthen the legal bargaining position of land-locked countries, even with states not parties to the Convention. The extent of concessions granted by Rhodesia, Portugal and South Africa to the land-locked countries would largely depend on the discretion of the former and are unlikely to meer all needs of the latter. Should the white minority regimes reject outright the demands of the land-locked countries, this would not only intensify the present isolation of Rhodesia, Portugal, and South Africa but also strengthen the conviction of those members of OAU who believe that the solution of the problems of the land-locked states of southern Africa (as well as all fundamental political, social, and economic problems in the region) lies in the termination of white minority and colonial rule in the region. 


\section{The Right of Access to the Sea of African Land-locked Countries}

\section{By Zdenek Červenka}

The paper examines the problems of African land-locked countries both in terms of their access to the sea and of access to the wide area of communications with the outside world. The author maintains that the free access to the sea is derived from the fundamental principle of international law on sovereign equality of all states. The article focuses on the position of land-locked states of southern Africa Botswana, Lesotho, Swaziland and Zambia - complicated by their involvement in the confrontation of independent Africa with the colonial regime of Portugal and the white supremacy of South Africa and Rhodesia. Finally, the article deals with the role of the OAU and the author suggests a convention governing free access to the sea of African land-locked countries under OAU auspices.

\section{Political Problems of Tanzania after Socialist Transformation of the Modern Sector of the Economy}

\section{By Helmut Bley}

The essay offers an interpretation of the causes and limitations of the Tanzanian socialist strategy since 1967, especially during the years 1970-1972. The paper is based on recent published and unpublished research in this field as well as on personal observations of the author. It tries to assess the balance of power within the coalition of social forces which won independence in Tanzania. Early TANU is understood as a heterogenous movement which did not indicate socialist tendencies. Key elements in the unexpected socialist turn in independent Tanzania were 1. Nyerere's policy against land-accumulation introduced already in the fifties which was backed by rural mass support for TANU; 2 . the necessity to gain national control over the modern sector of the economy and the financial resources in order to strengthen the country against international economic pressure. Political opposition against this policy was contained by excluding the cooperative movement which controls part of the cash-crop sector from the socialist strategy and by offering the urban elite, which lost investment opportunities, the chances of administering the increased nationalized sector. The framework of the One-Party system was used to enforce this option. The new situation after implementing the socialist policy is understood as a balance between a cabinet dominated by representatives of the underdeveloped regions, the new managerial elite in state bureaucracy and para-statal economic institutions and TANU Executive Committee, which is still able to mobilise rural and urban mass support. The peasantry producing for the modern sector are isolating themselves as long as the rural strategy of Ujamaa does not touch them. The years 1970-1972 are regarded as a period of crisis, where important sectors of the rural community were negatively affected by the policy of state control in distribution and felt threatened by elements of the Ujamaa campaigns, which indicated a policy of collectivizing agriculture.

Rural discontent and the increasing problems in keeping the level of productivity led in June 1972 to a new agricultural policy, renewing the old compromise of leaving the cooperative movement and family production outside the socialist sector but maintaining the policy against accumulation of land and labour. 